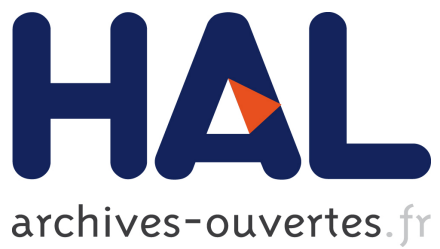

\title{
Life-Cycle Assessment of Microalgal-Based Biofuels
}

Pierre Collet, Daniele Spinelli, Laurent Lardon, Arnaud Hélias, Jean-Philippe Steyer, Olivier Bernard

\section{To cite this version:}

Pierre Collet, Daniele Spinelli, Laurent Lardon, Arnaud Hélias, Jean-Philippe Steyer, et al.. Life-Cycle Assessment of Microalgal-Based Biofuels. A. Pandey and D.-J. Lee and Y. Chisti and C. R. Soccol. Biofuels from algae, Elsevier, pp.287-312, 2013. < hal-00854438>

\section{HAL Id: hal-00854438 https://hal.inria.fr/hal-00854438}

Submitted on 27 Aug 2013

HAL is a multi-disciplinary open access archive for the deposit and dissemination of scientific research documents, whether they are published or not. The documents may come from teaching and research institutions in France or abroad, or from public or private research centers.
L'archive ouverte pluridisciplinaire $\mathbf{H A L}$, est destinée au dépôt et à la diffusion de documents scientifiques de niveau recherche, publiés ou non, émanant des établissements d'enseignement et de recherche français ou étrangers, des laboratoires publics ou privés. 


\section{Life Cycle Assessment of microalgal based biofuel}

Pierre Collet ${ }^{1}$, Daniele Spinelli ${ }^{2}$, Laurent Lardon $^{1}$, Arnaud Hélias ${ }^{1,3}$, Jean-Philippe Steyer ${ }^{1}$, Olivier Bernard $^{4}$

1 INRA UR0050, Laboratoire de Biotechnologie de I'Environnement, Avenue des Etangs, 11000 Narbonne, France

2 Department of Chemistry and Center for Complex System Investigation, University of Siena, Via Alcide de Gasperi 2, 53100 Siena, Italy

3 Montpellier SupAgro, 2 place Pierre Viala 34060 Montpellier, France

4 INRIA BIOCORE, BP 93, 06902 Sophia Antipolis Cedex, France

\section{Abstract}

Fossil fuel depletion and attempts of global warming mitigation have motivated the development of biofuels. Several feedstock and transformation pathways into biofuel have been proposed as an alternative to usual fuels. Recently, microalgae have attracted a lot of attention because of the promise of reduced competition with food crop and lowered environmental impacts. Over the last years, several Life Cycle Assessments have been realised to evaluate the energetic benefit and Global Warming Potential reduction of biofuel and bioenergy produced from microalgae. This chapter presents a bibliographic review of fifteen LCA of microalgae production and/or transformation into biofuel. These studies differ often by the perimeter of the study, the functional unit and the production technologies or characteristics. Methods for the environmental impacts assessment and the energy balance computation also diverge. This review aims at identifying the main options and variations between LCAs and concludes by some recommendations and guidelines to improve the contribution of an LCA and to facilitate the comparison between studies.

Keywords: Life Cycle Assessment (LCA), Microalgae, Renewable energy, Biofuel, Review, Guidelines 


\section{Introduction}

Environmental impacts and depletion of fossil energies have promoted the development of alternative and renewable sources of energy. Nonetheless it is clear now that the replacement of current fossil energy will require both the development of new strategies to reduce our global energy consumption and the development of a panel of renewable energy sources. Renewable energy can be extracted from solar, wind or geothermal energy. However these energy forms are globally hard to store and hence cannot yet replace our consumption of fossil fuel for some important functions such as powering cars and planes. So far, several paths have been explored to produce fuels from renewable sources, the most developed strategies leading to the production of so-called first and second generation biofuels. First generation biofuel are based on fuel production (ethanol or methylester) from a currently cultivated and harvested biomass (e.g. corn, rapeseed ...). Second generation biofuel corresponds to the development of new energy production pathways from usual feedstock non-reclaimed by food production (e.g. straw or wood). The development of first generation biofuel has been criticised, first, because of the direct competition they create with food crops in a context where food security is a raising concern, secondly because of their actual poor environmental performances. Indeed inputs production (e.g. fertilizer or pesticides), feedstock culture, harvest and transformation imply fuel consumption and lead to new emissions of pollutants (Börjesson and Tufvesson, 2011) and especially the emissions of greenhouse gas to the environment (Searchinger et al., 2008). Consequently energetic and environmental benefits of these biofuel are limited. Second generation biofuel improves the environmental performance but are not free of criticisms.

These observations advocate for the necessity of systematically assessing new energy production paths with a Life Cycle Assessment (LCA) perspective, which means, first, the adoption of a cradleto-grave perspective, i.e. looking at resource depletion, energy consumption and substance 
emissions of all the processes required to achieve the production and use of the fuel, and secondly, the assessment of several environmental impacts and not only global warming potential or net energy production. Life Cycle Assessment is an ISO method developed in this aim: it allows the detection of pollution transfer from one step to another one or from one kind of environmental impact to another one. The European Directive on renewable energy (European Union, 2009) adopted in 2009 embraces LCA as a reference method to assess environmental impacts of biofuel and fixes greenhouse gas reductions objectives of 50\% in 2017.

Third generation biofuel correspond to the development of bioenergy productions based on new feedstock reputed for their lower land competition. Microalgae belong to this third category. Their very high actual photosynthetic yield and their ability to accumulate lipids, or, for some species, starch, added to the possibility to be cultivated in controlled environment promise the possibility of biofuel with a low competition with food crop (Chisti, 2007) and with limited environmental impacts. In addition, the ability to use $\mathrm{CO}_{2}$ directly from industrial emissions as a resource of carbon for the growth of microalgae is a promising feature for flue gas mitigation (Huntley and Redalje, 2006; Chisti, 2007). However this promise should be challenged. So far microalgae industrial production has been developed only for the production of high-value molecules (such as beta-carotenes) or dietary supplement (Spirulina or Chlorella can be found as pills in health shops); hence energetic or environmental performances have never been a concern. Moreover, the scale of the existing facilities is far smaller than the one required for fuel production (at least several hundreds of ha). It is then necessary to assess the expected environmental performances of the potential production systems, in order to detect technological bottlenecks and to determine which processes should be optimized in priority. This approach is now necessary to design a sound, energetically efficient, and environmentally friendly biofuel production system. 
Since the new focus of international scientific and economic communities on microalgae-based biofuel, many environmental, energetic or economical assessments have been published, with different final energy carriers or different production assumptions. We propose here to review a set of publications, all of them published in peer-reviewed scientific journals, using the Life Cycle Assessment (LCA) method to assess the environmental impacts linked to microalgae based biofuel. The lack of real industrial facility dedicated to energy production from microalgae imposes the use of models and extrapolations to describe the production systems. Besides, system frontiers and coproduct management differ between the studies. All in one, this leads to divergences between publications results. This review aims to identify and explain this variability and then to propose guidelines to improve future LCAs of algal-based bioenergy production systems. This work is a mirror of this diversity and underlines the difficulty to compare different studies without common assumptions.

\section{Assessed functions, associated functional units and perimeters of microalgae production LCAs}

The main selection criterion has been a clear definition of a functional unit. The concept of Functional Unit (FU) is the main characteristic of LCA (Udo de Haes et al., 2006) and allows relevant and fair comparisons between studies or between different technological options. Here, the studies are briefly described:

- Kadam (2002) (Kad): comparative LCA of electricity production from coal only or from coal and microalgal biomass. Half of the $\mathrm{CO}_{2}$ emitted from the power plant is assumed to be captured by a monoethanolamine (MEA) process.

- Lardon et al. (2009) (Lar): LCA of biodiesel production in open raceways with or without nitrogen stress and with wet or dry extraction of the lipids. 
- Baliga and Powers (2010) (Bal): LCA of biodiesel production in photobioreactors located in cold climate. Cultivation is realised under greenhouses, heats losses from a local power plant are used as heat source.

- Batan et al. (2010) (Bat): LCA of biodiesel production in photobioreactors based on the GREET model (Greenhouse Gases, Regulated Emissions and Energy use in Transportation).

- Clarens et al. (2010) (Cla10): comparative LCA of the energetic content of microalgae with terrestrial crops used as biofuels feedstock. Microalgae are cultivated in open raceways with chemical fertilizers.

- Jorquera et al. (2010) (Jor): comparative LCA of microalgal biomass production in open raceways, tubular photobioreactors and flat plate photobioreactors.

- Sander and Murthy (2010) (San): LCA of biodiesel production in open raceways based on the GREET model with a culture in two stages (first, photobioreactors, then open-raceways).

- Stephenson et al. (2010) (Ste): comparative LCA of biodiesel production in open raceways and photobioreactors. Oil extraction residues are treated by anaerobic digestion; the digestates are used as fertilizers.

- Brentner et al. (2011) (Bre): combinatorial LCA of industrial production of microalgal biodiesel. The base configuration consists in cultivation in open raceways, hexane extraction of dry algae and methanol transesterification, oilcakes are considered as a waste; the optimised configuration is composed of cultivation in PBR, extraction with in situ esterification by supercritical methanol, anaerobic digestion of oilcakes and use of the digestates as fertilizers.

- Campbell et al. (2011) (Cam): LCA and economic analysis of biodiesel production in open ponds. Pure $\mathrm{CO}_{2}$ produced during the synthesis of nitrogen fertilizer is used as source of carbon.

- Clarens et al. (2011) (Cla11): LCA of algae-derived biodiesel and bioelectricity for transportation. Four types of bioenergy production are compared: (A) anaerobic digestion of bulk microalgae for bioelectricity production, (B) biodiesel production with anaerobic digestion of oilcakes to produce bioelectricity, (C) biodiesel production with combustion of oilcakes to produce 
bioelectricity, (D) direct combustion of microalgae biomass to produce bioelectricity. Four ways to supply nutrients are compared: (1) pure $\mathrm{CO}_{2},(2) \mathrm{CO}_{2}$ captured from a local coal power plant, (3) $\mathrm{CO}_{2}$ in fluegas, (4) $\mathrm{CO}_{2}$ in fluegas and nutrients in waste water.

- Collet et al. (2011) (Col): LCA of biogas production from anaerobic digestion of bulk microalgae. Biomass is grown in open raceways, digestates are used as fertilizers.

- Hou et al. (2011) (Hou): LCA of biodiesel from microalgae and comparison with soybean and jatropha.

- Khoo et al. (2011) (Kho): LCA of biodiesel from microalgae; cultivation is carried out in two phases, first in photobioreactors then in open raceway.

- Yang et al. (2011) (Yan): LCA of biodiesel production limited to water and nutrients consumptions.

Among the 15 selected papers, two functions are assessed: either biomass production (two publications) or bioenergy production (14 publications). Three final vectors for the bioenergy are considered: methylester (11 publications), methane ( 2 publications), and electricity (2 publications). It is worth noticing that these different energy carriers have different characteristics. Methane and methylester are easily storable, unlike electricity. There is also an important diversity of functional units (FU). Most of the studies focus on the production of biodiesel as the main energy output from microalgae. The amount of biodiesel produced is described in different units: volume (Baliga and Powers, 2010), mass (Stephenson et al., 2010) or energy content (Lardon et al., 2009). Unfortunately there is no consensus on the values of energy content or on the mass density of algal oil and algal methylester; in addition, the description of the energy content is not harmonised and can be based either on the Lower Heating Value (LHV) or on the High Heating Value (HHV). Finally among the studies dedicated to the biodiesel production, six are well-to-pump studies, which means that the use of the fuel is not included in the perimeter (Baliga et Powers, 2010; Batan et al., 2010; Sander and Murthy, 2010; Brentner et al., 2011; Khoo et al., 2011; Yang et al., 2011), and five are well-to- 
wheel studies, where the use of the fuel is included (Lardon et al., 2009; Stephenson et al., 2010;

Campbell et al., 2011; Clarens et al., 2011; 2011; Hou et al., 2011).

This diversity of Functional Units leads to a diversity of perimeters for the inventory. Table 1 summarizes the assessed systems. The different steps potentially included in the perimeter of the study can be classified among five categories: production of the inputs required for the cultivation (I), cultivation $(\mathrm{C})$, harvesting and conditioning of microalgae $(\mathrm{H})$, transformation into different types of energy carrier $(T)$, and, eventually, use of the produced energy $(U)$.

Table 1 - Functional Unit and perimeter of selected studies.

\begin{tabular}{|c|c|c|c|c|c|c|c|}
\hline \multirow{2}{*}{ Ref } & \multirow{2}{*}{ Functional unit } & \multirow{2}{*}{ Heating value } & \multicolumn{5}{|c|}{ Perimeter } \\
\hline & & & I & $\mathrm{C}$ & $\mathrm{H}$ & $T$ & $\mathrm{U}$ \\
\hline Kad & Production of $1 \mathrm{MWh}$ of electricity & - & & & & & \\
\hline Lar & Combustion of $1 \mathrm{MJ}$ of biodiesel & $37.8 \mathrm{MJ}_{\mathrm{LHV}} \cdot \mathrm{kg}^{-1}$ & & & & & \\
\hline Bal & Production of 1L of biodiesel & - & & & & & \\
\hline Bat & Production of $1 \mathrm{MJ}$ of biodiesel & - & & & & & \\
\hline Cla10 & Production of 317 GJ of algae & $\mathrm{MJ}_{\mathrm{HHV} \cdot \mathrm{kg}^{-1}}$ & & & & & \\
\hline Jor & Production of 100 t DM of algae & - & & & & & \\
\hline San & Production of $1000 \mathrm{MJ}$ of biodiesel & $41.2 \mathrm{MJ}_{\mathrm{HHV}} \cdot \mathrm{kg}^{-1}$ & & & & & \\
\hline Ste & Combustion of $1 \mathrm{t}$ of biodiesel & $\mathrm{MJ}_{\mathrm{LHV}} \cdot \mathrm{kg}^{-1}$ & & & & & \\
\hline Bre & Production of $10 \mathrm{GJ}$ of algal methylester & 34 MJ-HHV.kg-1 & & & & & \\
\hline Cam & Carriage of $1 \mathrm{t} . \mathrm{km}$ & - & & & & & \\
\hline Cla11 & Vehicule Kilometer Travelled & $23.1 \mathrm{MJ}-\mathrm{X} . \mathrm{kg}-1$ & & & & & \\
\hline Col & Combustion of $1 \mathrm{MJ}$ of methane & $6.96 \mathrm{MJ}_{\mathrm{LHV}} \cdot \mathrm{m}^{-3}$ & & & & & \\
\hline Hou & Combustion of $1 \mathrm{MJ}$ of biodiesel & - & & & & & \\
\hline Kho & Production of $1 \mathrm{MJ}$ of biodiesel & $40 \mathrm{MJ}_{\mathrm{LHV}} \cdot \mathrm{kg}^{-1}$ & & & & & \\
\hline Yan & Production of $1 \mathrm{~kg}$ of biodiesel & - & & & & & \\
\hline
\end{tabular}

Figures 1 and 2 illustrate the different options met in the selected LCAs. The culture phase is the more consensual with two options, open raceways or photobioreactors. The transformation phase is the one with the largest number of alternatives, including the final energy carrier or the fate of the co-products. 


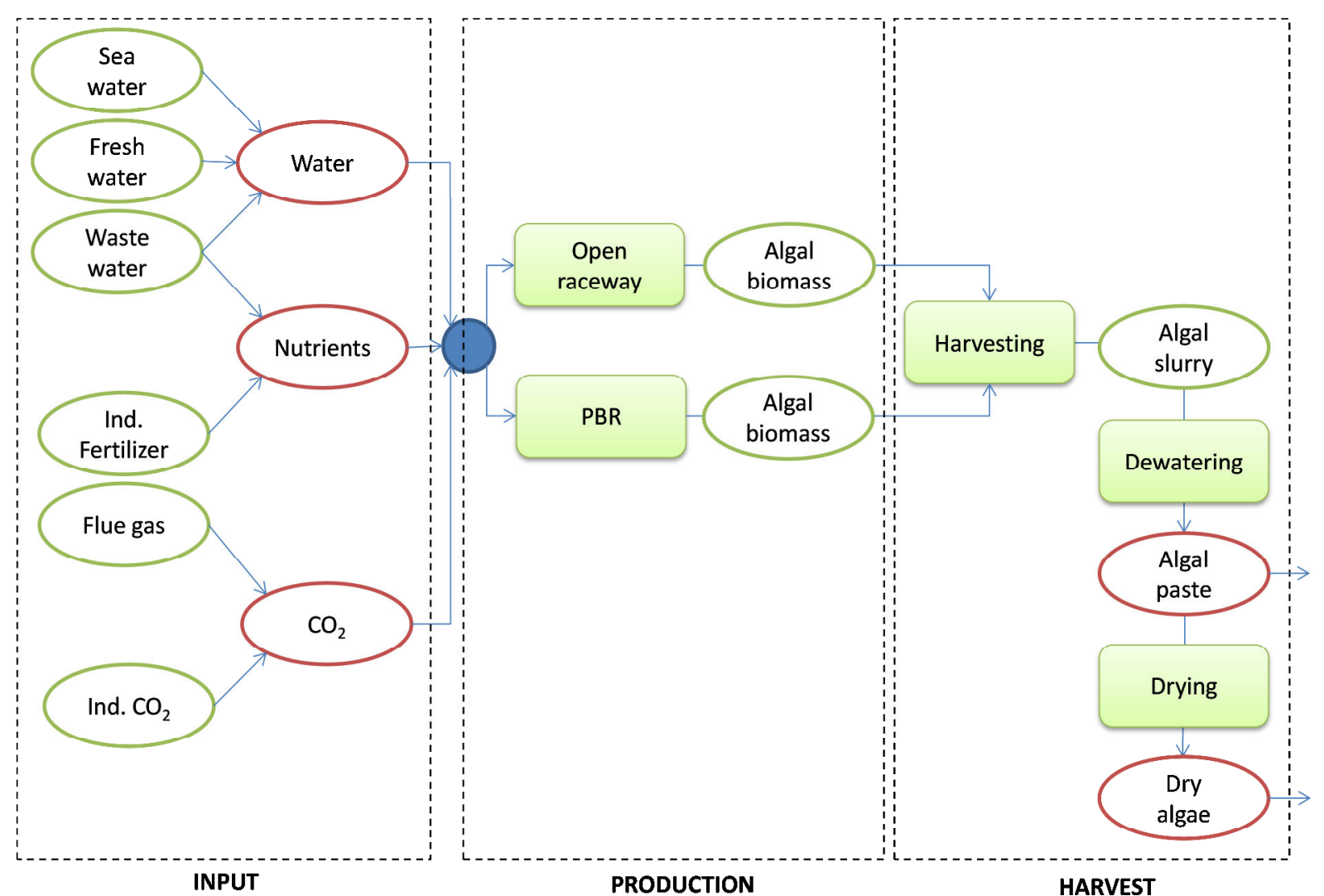

Figure 1 - System diagram for input, biomass production and biomass conditioning.

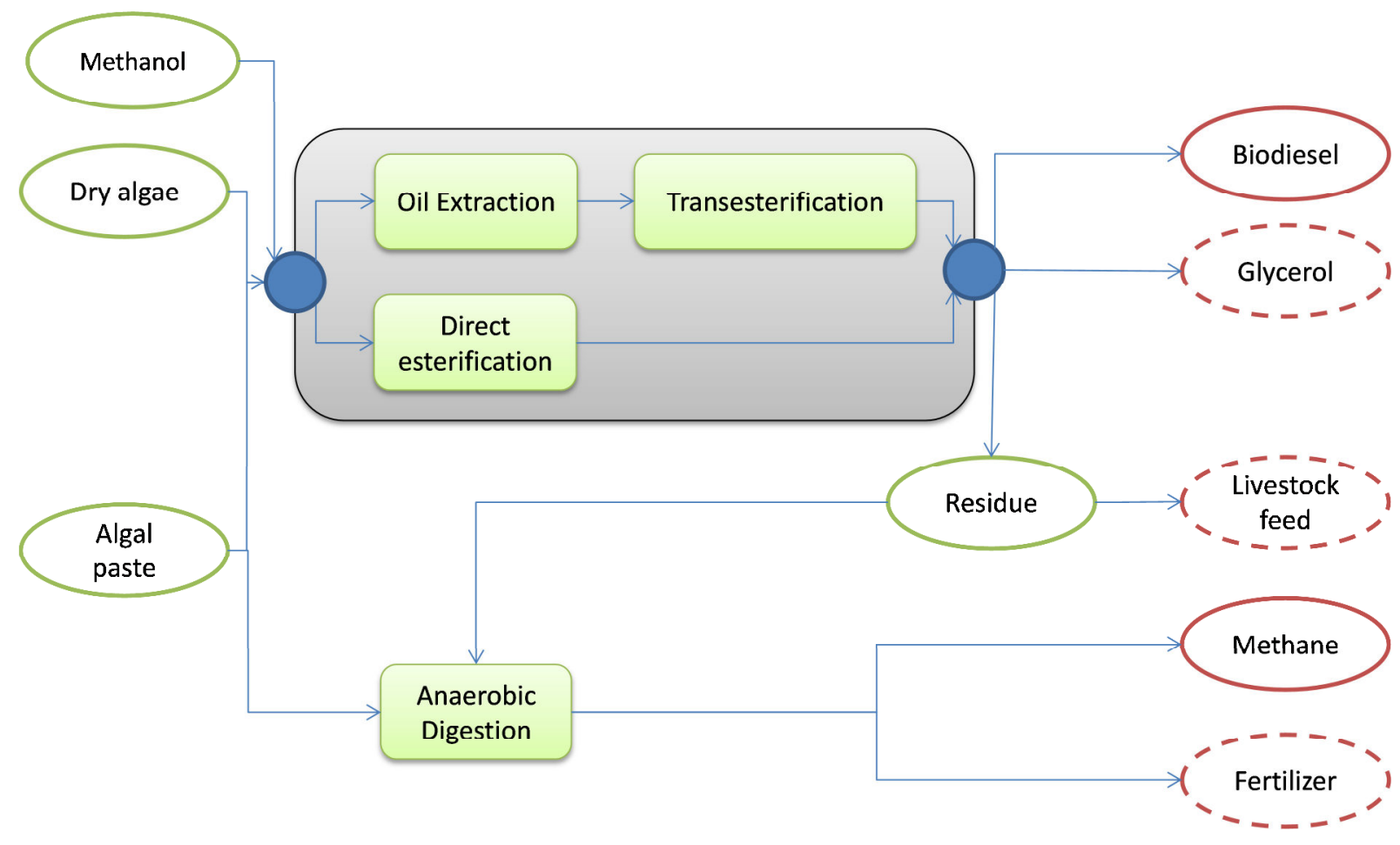

Figure 2 - System diagram for biomass transformation (UF: plain circles, Co-products: dashed circles) 


\section{Modelling of the inventory data}

According to the LCA method, once the functional unit, the perimeter of the study and the system have been defined, each process included in the perimeter has to be characterized in terms of technical inputs and outputs, energy and resource consumption, and emissions toward the environment. Because of the lack of industrial data on microalgae culture or transformation, the inventory data compiled in the selected studies often relies either on extrapolation from lab-scale results, either on adaptation from similar processes used in different conditions or with different feedstock, or either on modelling.

\subsection{Choice of the inputs}

The input category refers here to any product or service required at some point of the microalgae culture or transformation. It includes the materials used to build cultivation systems, fertilizers and chemical reactants, production of electricity and heat required at the facility. Almost all the publications consider in an exhaustive ways these inputs, except:

- Jorquera et al. (2010) : fertilisers are not taken into account.

- Clarens et al. $(2010,2011)$ : infrastructures are not taken into account.

- Sander et Murthy (2010) : only flows which contribute to more than $5 \%$ of the total mass, energy and economy are taken into account.

The energy and the fertilizer are the most influencing inputs for the final environmental performance and energy balance:

\section{Energy}

Table 2 specifies the electricity and heat sources used in the different publications. The electricity mix is determined by the country where the production is supposed to take place ; in some publications, 
electricity and heat consumptions are totally or partially covered by internal production from the microalgae, either by anaerobic digestion of the oilcakes (Stephenson et al., 2010; Brentner et al., 2011; Campbell et al., 2011; Clarens et al., 2011), of the algal biomass (Clarens et al., 2011; Collet et al., 2011), or by direct combustion of microalgal biomass or extraction residue (Clarens et al., 2011).

Table 2: Energy sources used to produce biomass and biofuels from microalgae

\begin{tabular}{|c|c|c|c|c|c|c|c|c|c|c|c|}
\hline \multirow[b]{2}{*}{ Energy } & \multicolumn{8}{|c|}{ Electricity } & \multicolumn{3}{|c|}{ Heat } \\
\hline & $\begin{array}{l}\text { Mix } \\
\text { USA }\end{array}$ & $\begin{array}{l}\text { Mix } \\
\text { UK }\end{array}$ & $\begin{array}{l}\text { Mix } \\
\text { EU }\end{array}$ & $\begin{array}{c}\text { Mix } \\
\text { Australia }\end{array}$ & $\begin{array}{c}\text { Mix } \\
\text { China }\end{array}$ & Coal & Algae & NC & $\begin{array}{c}\text { Natural } \\
\text { gas }\end{array}$ & Algae & NC \\
\hline Ref & $\begin{array}{c}\text { Bal, } \\
\text { Bat } \\
\text { Cla10, } \\
\text { San, } \\
\text { Cla11 }\end{array}$ & Ste & $\begin{array}{l}\text { Lar, } \\
\text { Col }\end{array}$ & Cam & Hou & Kad & $\begin{array}{c}\text { Ste } \\
\text { Bre } \\
\text { Cam } \\
\text { Cla11 }\end{array}$ & $\begin{array}{l}\text { Jor, } \\
\text { Kho, } \\
\text { Yan }\end{array}$ & $\begin{array}{c}\text { Kad, } \\
\text { Lar, } \\
\text { Bal, } \\
\text { Bat, } \\
\text { San, } \\
\text { Cla11, } \\
\text { Hou }\end{array}$ & $\begin{array}{c}\text { Ste, } \\
\text { Bre, } \\
\text { Cla11, } \\
\text { Col }\end{array}$ & $\begin{array}{l}\text { Cam, } \\
\text { Kho } \\
\text { Yan }\end{array}$ \\
\hline
\end{tabular}

NC : non communicated

Most of the authors (Lardon et al., 2009; Baliga et Powers, 2010; Sander and Murthy, 2010; Stephenson et al., 2010; Khoo et al., 2011) have underlined the important contribution of energy consumption to the Global Warming Potential of algal energy productions. The sensitivity of this choice has been assessed with inventories from the Ecolnvent database and the ReCiPe impact assessment method (Goedkoop et al., 2009) in a hierarchist perspective. With this perspective, characterization factors of the Global Warming Potential are the ones defined by the IPCC (IPCC, 2006). As shown by Figure 3, climate change impact can vary by a factor two according to the chosen electric mix. Consequently the potential reduction of greenhouse gases by producing bioenergy from microalgae is strongly correlated with the origin of the electricity. It is important to notice that the variations of every endpoint impacts (i.e. human health, ecosystems, and resources) are almost identical to the one of the climate change impact. This underlines the strong dependence of all the impacts to the energy mix composition. 


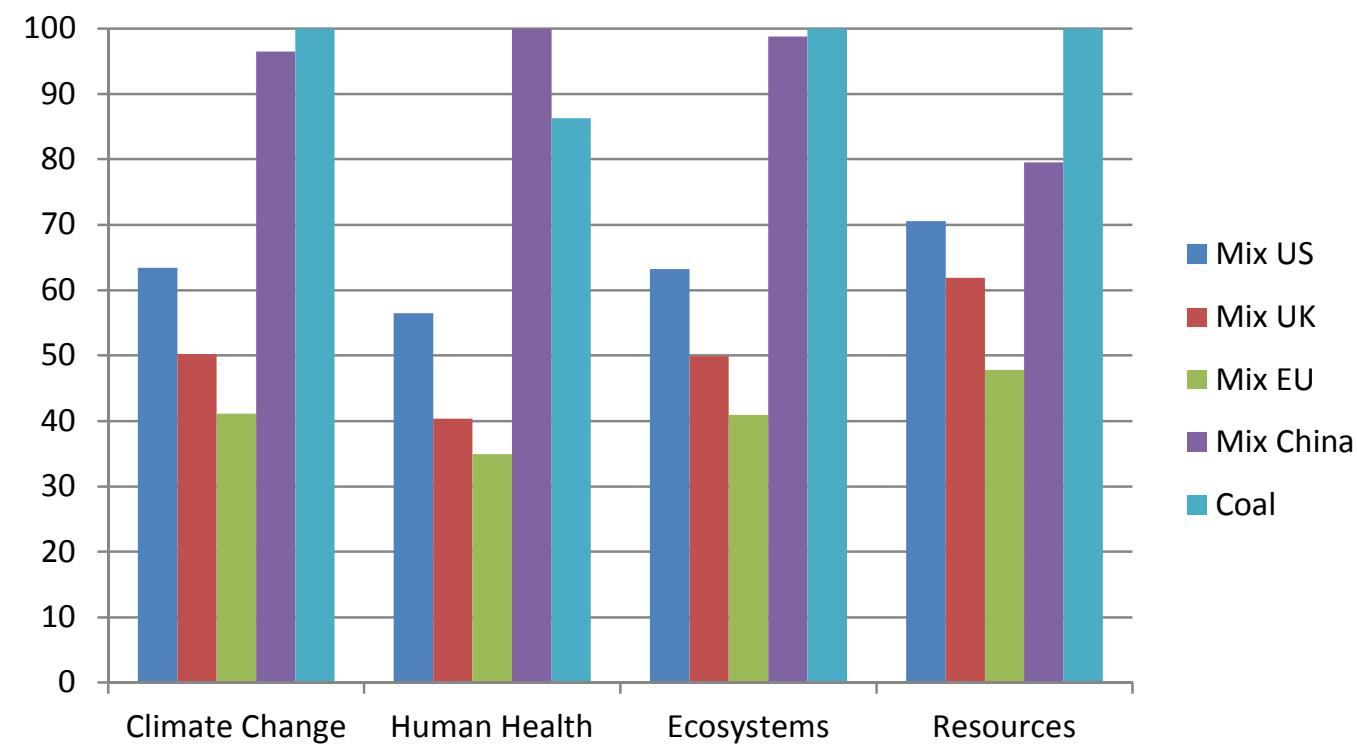

Figure 3: Climate change and endpoint impacts of different electric mix (percentage of the worst case by impact category)

\section{Nutrients}

Nutrients requirement is known to depend on the species, but also on the stress which has been induced to stimulate lipid or carbohydrate storage. The nitrogen and phosphorus quota can strongly vary during a starvation period (Geider and La Roche, 2002). The hypotheses on required fertilizers strongly vary according to the species, and between the publications for a same species (Lardon et al., 2009; Stephenson et al., 2010; Yang et al., 2011). Needs in nitrogen vary from 10.9 g.kgDM-1 (Lardon et al., 2009) to 20.32 g.kgDM ${ }^{-1}$ (Stephenson et al., 2010) in limiting conditions, and from 9.41 g.kgDM ${ }^{-1}$ (Kadam, 2002) to 77.6 g.kgDM ${ }^{-1}$ (Clarens et al., 2011) without stress. Needs in phosphorus vary from 2.4 g.kgDM ${ }^{-1}$ (Lardon et al., 2009) to 2.58 g.kgDM ${ }^{-1}$ (Khoo et al., 2011) in limiting conditions, and from 0.02g.kgDM ${ }^{-1}$ (Kadam, 2002) to 71 g.kgDM ${ }^{-1}$ (Yang et al., 2011) without stress. All the authors agree on the high nutrient consumption for the culture of microalgae but they differ by the ways to provide them (see Table 3). Some authors like Sander and Murthy (2010) and Clarens et al. $(2010,2011)$ consider that the needs in nitrogen and phosphorus can be totally or partially covered by the addition of wastewater to the growth medium. But in most of the publications, 
nutrients are provided by chemical fertilizers. In order to reduce the nutrient consumption, several authors suggest to recycle the digestates resulting from the anaerobic digestion of oilcakes (Stephenson et al., 2010; Brentner et al., 2011; Campbell et al., 2011; Clarens et al., 2011) or of bulk microalgae (Clarens et al., 2011; Collet et al., 2011).

Table 3: Different sources of nutrients used for microalgae cultivation

\begin{tabular}{|c|c|c|c|c|c|c|c|c|c|}
\hline \multirow[b]{2}{*}{ Ref } & \multicolumn{3}{|c|}{ Nitrogen } & \multicolumn{3}{|c|}{ Phosphorus } & \multicolumn{3}{|c|}{ Potassium } \\
\hline & Mineral & $\begin{array}{l}\text { Organic and } \\
\text { recycled }\end{array}$ & NC & Mineral & $\begin{array}{l}\text { Organic and } \\
\text { recycled }\end{array}$ & NC & Mineral & $\begin{array}{c}\text { Organic } \\
\text { and } \\
\text { recycled }\end{array}$ & NC \\
\hline Kad & Ammonia & - & - & $\begin{array}{c}\text { Single } \\
\text { superphosphate }\end{array}$ & - & - & $\begin{array}{l}\text { Potassium } \\
\text { sulphate }\end{array}$ & - & - \\
\hline Lar & $\begin{array}{l}\text { Calcium } \\
\text { nitrate }\end{array}$ & - & - & $\begin{array}{c}\text { Single } \\
\text { superphosphate }\end{array}$ & - & - & $\begin{array}{l}\text { Chloride } \\
\text { potassium }\end{array}$ & - & - \\
\hline Bal & - & - & $x$ & - & - & $x$ & - & - & - \\
\hline Bat & - & - & $x$ & - & - & $x$ & - & - & - \\
\hline Cla10 & - & $\begin{array}{c}\text { Urea, } \\
\text { Wastewater }\end{array}$ & - & $\begin{array}{c}\text { Single } \\
\text { superphosphate }\end{array}$ & Wastewater & & - & - & - \\
\hline Jor & - & - & - & - & - & - & - & - & - \\
\hline San & - & Wastewater & - & - & Wastewater & - & - & - & - \\
\hline Ste & $\begin{array}{l}\text { Ammonium } \\
\text { nitrate }\end{array}$ & - & - & $\begin{array}{c}\text { Triple } \\
\text { superphosphate }\end{array}$ & - & - & - & - & - \\
\hline Bre & $\begin{array}{l}\text { Ammonium } \\
\text { nitrate }\end{array}$ & & & $\begin{array}{c}\text { Calcium } \\
\text { phosphate }\end{array}$ & - & - & - & - & - \\
\hline Cam & - & - & $x$ & - & - & $x$ & - & - & - \\
\hline Cla11 & $\begin{array}{l}\text { Ammonium } \\
\text { phosphate }\end{array}$ & Digestates & - & $\begin{array}{l}\text { Ammonium } \\
\text { phosphate }\end{array}$ & Digestates & - & - & - & - \\
\hline Col & $\begin{array}{l}\text { Ammonium } \\
\text { sulphate }\end{array}$ & Digestates & - & $\begin{array}{c}\text { Single } \\
\text { superphosphate }\end{array}$ & Digestates & - & $\begin{array}{l}\text { Chloride } \\
\text { potassium }\end{array}$ & Digestates & - \\
\hline Hou & - & - & $X$ & - & - & $x$ & - & - & - \\
\hline Kho & $\begin{array}{l}\text { Sodium } \\
\text { nitrate }\end{array}$ & - & - & $\begin{array}{l}\text { Sodium } \\
\text { phosphate }\end{array}$ & - & - & - & - & - \\
\hline Yan & - & - & $x$ & - & - & $x$ & - & - & $x$ \\
\hline
\end{tabular}

Figure 4 shows environmental impacts of different fertilizer sources. As previously seen for the energy mix, the source of nutrients can also have important consequences on the environmental balance of the energy production from microalgae. Climate change impact and endpoint impacts "Human Health" and "Ecosystem" can vary by a factor two according to the chosen nitrogen fertilizer. For these three impacts, ammonium nitrate is the worst one, and the impacts of ammonium sulphate, calcium nitrate and urea are quite the same. Concerning the resources consumption, urea is the worst one, mainly because of the high amount of natural gas used for its production. Clarens et al. $(2010,2011)$ and Sander and Murthy, (2010) suggest to use wastewaters 
to grow algae. This assumption allows reducing the consumed quantities of freshwater and chemical fertilizers. However, mineral elements' content in wastewaters can strongly vary depending on the place and the period of the year. For these reasons, in our point of view, it seems very difficult to rely on such fertilizers.

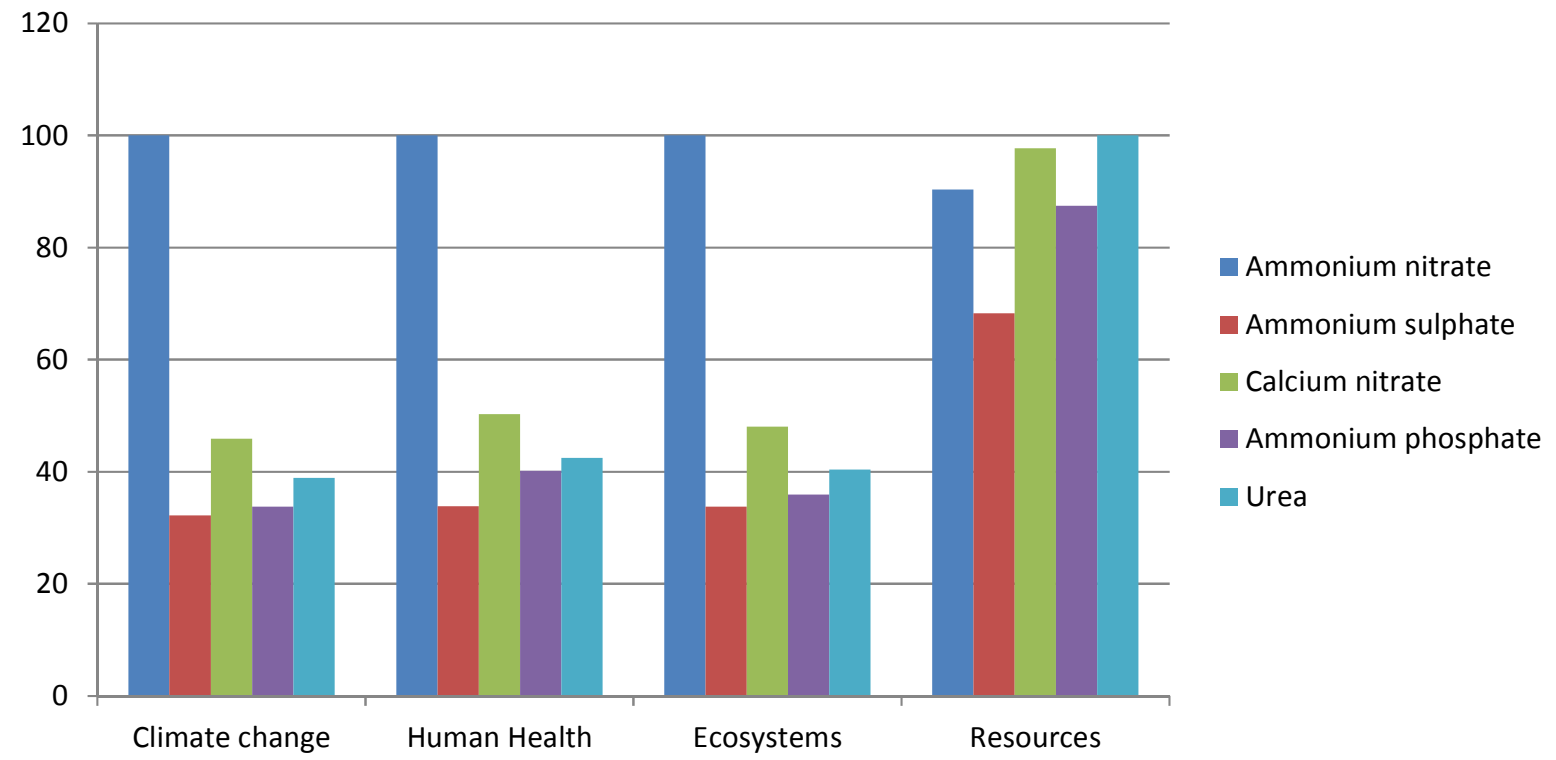

Figure 4: Climate change and endpoint impacts of different fertilizers (percentage of the worst case by impact category)

\subsection{Cultivation of the microalgae}

\section{Cultivation system and growth medium}

Microalgae cultivation is generally realised in two kinds of systems: open raceways (ORW) or photobioreactors (PBR). ORWs are shallow ponds (between 10 and $50 \mathrm{~cm}$ depth). They can be built in concrete (Lardon et al., 2009) or simply carved from the ground (Campbell et al., 2011) and can be recovered by a plastic liner made of high density polyethylene, HDPE) (Collet et al., 2011) or polyvinylchloride (PVC). Ponds are generally open but can be sheltered under a greenhouse. This kind of system is commonly used in the industry to produce microalgae used as foodstuffs (Shimamatsu, 2004; Del Campo et al., 2007). PBRs are closed systems allowing the intensification of the culture. There are numerous types and very different designs of PBR. They can be tubular (TPBR) or made of 
flat panels (FPBR) (Jorquera et al., 2010), or more rustically made of simple polyethylene bags soaked in a thermostatic water bath (Batan et al., 2010).

The choice of the growth medium can be done independently from the cultivation system. Depending on the chosen species, algae can be cultivated in fresh water, brackish water or sea water. The use of wastewater has also been suggested by several authors (Clarens et al., 2010, 2011; Sander and Murthy, 2010), offering the double advantage of a non-reclaimed source of water and nutrients. However it should be acknowledged that microalgae grown on wastewater could not be used afterwards as feedstock for fish or cattle. Water consumption has been identified as one of the main environmental concerns of bioenergy production from microalgae. Consequently some authors suggest growing algae in sea water, in order to have an unlimited resource (Batan et al., 2010; Khoo et al., 2011). Brackish water from groundwater is also used in some systems (Clarens et al., 2011). It should be noticed that fresh water is still required in these systems in order to stabilize the salinity. Table 4 lists cultivation systems, growth media and cultivated species mentioned in the selected studies. 
Table 4: Cultivation systems, growth mediums and cultivated species

\begin{tabular}{|c|c|c|c|c|c|c|c|}
\hline \multirow{2}{*}{ Ref } & \multicolumn{2}{|c|}{$\begin{array}{c}\text { Cultivation } \\
\text { system }\end{array}$} & \multicolumn{4}{|c|}{ Growth medium } & \multirow{2}{*}{ Cultivated species } \\
\hline & ORW & PBR & $\begin{array}{l}\text { Fresh } \\
\text { water }\end{array}$ & Sea water & $\begin{array}{c}\text { Brackish } \\
\text { water }\end{array}$ & $\begin{array}{l}\text { Waste } \\
\text { water }\end{array}$ & \\
\hline Kad & $\mathrm{X}$ & & & $X$ & $\mathrm{x}$ & & NC \\
\hline Lar & $\mathrm{X}$ & & $\mathrm{X}$ & & & & Chlorella vulgaris \\
\hline Bal & & $\mathrm{X}$ & & $x$ & & & Phaeodactylum tricornutum \\
\hline Bat & & $\mathrm{X}$ & & $\mathrm{X}$ & & & Nannochloropsis salina \\
\hline Cla10 & $\mathrm{X}$ & & $x$ & & & $\mathrm{X}$ & NC \\
\hline Jor & $\mathrm{X}$ & $\mathrm{X}$ & & $x$ & & & Nannochloropsis sp. \\
\hline San & $\mathrm{X}$ & & & & & $x$ & $\mathrm{NC}$ \\
\hline Ste & $\mathrm{X}$ & $\mathrm{X}$ & $\mathrm{X}$ & & & & Chlorella vulgaris \\
\hline Bre & $x$ & $x$ & $x$ & & & & Scenedesmus dimorphus \\
\hline Cam & $\mathrm{X}$ & & & $\mathrm{X}$ & & & NC \\
\hline Cla11 & $x$ & & & & $x$ & $x$ & $\begin{array}{l}\text { Tetraselmis sp., Cyclotella sp., } \\
\text { Dunaliella sp., } \\
\text { Phaeodactylum tricornutum }\end{array}$ \\
\hline Col & $\mathrm{X}$ & & $\mathrm{X}$ & & & & Chlorella vulgaris \\
\hline Hou & $\mathrm{X}$ & & & $\mathrm{X}$ & & & $\mathrm{NC}$ \\
\hline Kho & $x$ & $x$ & & $x$ & & & Nannochloropsis sp. \\
\hline Yan & $x$ & & $x$ & & & & Chlorella vulgaris \\
\hline
\end{tabular}

\section{Operating conditions}

Mineral composition, $\mathrm{C} / \mathrm{N}$ ratio and growth-rate of microalgae vary naturally according to environmental conditions (light and temperature), availability of nutrients or occurrence of stress. For instance the application of nitrogen starvation induces, for some species, the storage of lipids (Ketchum and Redfield, 1949). However the increase of lipid content is done to the detriment of cell division, and consequently the mass productivity is lower. Consequently, it should be highlighted that all these properties are correlated and cannot be determined on the basis of independent assumptions or sources.

As shown on Table 5, a large variability of productivity, lipid fraction or nutrient requirement is observed between the different studies. In 4 publications (Lardon et al., 2009; Batan et al., 2010; Stephenson et al., 2010; Khoo et al., 2011), authors suggest to impose nitrogen deprivation to the algae. To overcome the problem of the growth-rate reduction under nutrient stresses, some authors suggest cultivating microalgae in two steps. Firstly microalgal biomass is cultivated in nitrogen- 
replete conditions in order to reach a high growth-rate. Then microalgae are submitted to nitrogen deprivation to increase their lipid content.

Table 5: Operating conditions and needs in fertilizers for microalgae cultivation

\begin{tabular}{|c|c|c|c|c|c|c|c|c|}
\hline \multirow[b]{2}{*}{ Ref } & \multirow{2}{*}{$\begin{array}{l}\text { Growth } \\
\text { rate } \\
\left(\mathrm{g} \cdot \mathrm{m}^{-2} \cdot \mathrm{d}^{-1}\right) \\
\left(\mathrm{g} \cdot \mathrm{m}^{-3} \cdot \mathrm{d}^{-1}\right)^{*}\end{array}$} & \multirow[b]{2}{*}{$\begin{array}{c}\text { Concentration } \\
\left(\text { g. } \mathrm{L}^{-1}\right)\end{array}$} & \multirow[b]{2}{*}{$\begin{array}{c}\text { Nitrogen } \\
\text { deprivation }\end{array}$} & \multirow[b]{2}{*}{$\begin{array}{l}\text { Lipid } \\
(\%)\end{array}$} & \multicolumn{4}{|c|}{ Nutrients (g. $\left.\mathrm{kg}^{-1} \mathrm{DM}\right)$} \\
\hline & & & & & $\mathrm{N}$ & $P$ & K & $\mathrm{CO}_{2}$ \\
\hline Kad & 31.4 & 0.8 & No & 50 & 9.41 & 0.02 & 0.01 & 2.16 \\
\hline & 24.75 & 5 & No & 17.5 & 46 & 9.9 & 8.2 & 1.8 \\
\hline Lar & 19.25 & 0.3 & Yes & 38.5 & 10.9 & 2.4 & 2.0 & 2.0 \\
\hline Bal & - & 3.4 & No & 30 & 65 & 13 & - & 0.51 \\
\hline Bat & 25 & - & Yes & 50 & - & - & - & - \\
\hline Cla10 & 40.6 & 1 & No & - & 70 & 14.73 & - & 1.6 \\
\hline Jor & $\begin{array}{c}\text { ORW: } 35 \\
\text { FPBR : } 270^{*} \\
\text { BPR : } 560^{*}\end{array}$ & $\begin{array}{l}\text { ORW: } 0.35 \\
\text { FPBR }: 2.7 \\
\text { TPBR : } 1.02\end{array}$ & No & 29.6 & - & - & - & - \\
\hline San & - & 0.5 & No & 30 & - & - & - & - \\
\hline Ste & $\begin{array}{c}\text { ORW : } 30 \\
\text { PBR : } 1000^{*}\end{array}$ & $\begin{array}{c}\text { ORW : } 1.67 \\
\text { PBR }: 8.3\end{array}$ & Yes & 50 & 20.32 & - & - & 2.30 \\
\hline Bre & $\begin{array}{c}\text { ORW : } 27.5 \\
\text { PBR : } 1536 \\
*\end{array}$ & $\begin{array}{c}\text { ORW : } 0.47 \\
\text { PBR : } 4\end{array}$ & No & 31.25 & 82 & 10 & - & 1.79 \\
\hline Cam & 30 & - & No & - & 5.6 & 0.56 & - & 1.68 \\
\hline Cla11 & 27.9 & 1.4 & No & 19.6 & $\begin{array}{c}77.6 \\
\text { (including } \\
\text { wastewaters) }\end{array}$ & $\begin{array}{c}5.17 \\
\text { (including } \\
\text { wastewaters) } \\
\end{array}$ & - & 2.36 \\
\hline Col & 25 & 0.5 & No & - & 61 & 8.1 & 6.59 & 1.345 \\
\hline Hou & 30 & - & No & 45 & 5.5 & 0.56 & - & 1.68 \\
\hline Kho & $\begin{array}{l}\text { ORW : } 25 \\
\text { PBR : NC }\end{array}$ & 0.5 & Yes & 25 & 24.7 & 2.58 & - & 1.83 \\
\hline Yan & 35 & 1 & No & 35 & 33 & 71 & 58 & - \\
\hline
\end{tabular}

Growth rate is known to be species dependent, and strongly influenced by light and temperature (Falkowski and Raven, 1997). It can be strongly reduced by the stress protocol used to induce lipid accumulation by nutrient deprivency (Lacour et al., 2012). Depending on the location, cultivation system, species and protocol, growth rate can, and biomass concentration can therefore vary for more than an order of magnitude. The hypotheses made in LCA studies reflect this large spectrum. In ORW, growth rates vary from 25 (Batan et al., 2010; Collet et al., 2011) to $40.6 \mathrm{~g} \cdot \mathrm{m}^{-2} \cdot \mathrm{d}^{-1}$ (Clarens et al., 2010). In PBR, productivities are much higher and vary from 270 (Jorquera et al., 2010) to $1536 \mathrm{~g} \cdot \mathrm{m}^{-3} \cdot \mathrm{d}^{-1}$ (Brentner et al., 2011). The PBR conception has a strong influence on the growth rate (Jorquera et al., 2010). Microalgae concentration range from 0.5 (Lardon et al., 2009) to 1.67 g.L ${ }^{-1}$ 
(Stephenson et al., 2010) in an ORW, and from 1.02 (Jorquera et al., 2010) to 8.3 g.L $^{-1}$ (Stephenson et al., 2010) in a PBR. Expected lipid contents vary broadly between authors: from $17.5 \%$ (Lardon et al., 2009) to $50 \%$ (Kadam, 2002) without nitrogen deprivation, and from $25 \%$ (Khoo et al., 2011) to 50\% with nitrogen deprivation (Batan et al., 2010; Stephenson et al., 2010).

\section{Quantity and quality of $\mathrm{CO}_{2}$}

$\mathrm{CO}_{2}$ must be supplied to the growth medium to reach high algal productivities. It has been shown that, provided that $\mathrm{pH}$ was regulated, the microalgae can be very tolerant to the source of $\mathrm{CO}_{2}$ (Doucha et al., 2005). However, the dissolution efficiency together with the ability of microalgae to consume this $\mathrm{CO}_{2}$ are very dependent on the cultivation system. The supply rate in the LCA studies ranges from 0.51 to $2.36 \mathrm{kgCO}_{2} \cdot \mathrm{kgDM}^{-1}$. Depending on the studies, $\mathrm{CO}_{2}$ is supplied from compressed and purified gas or from the flue gas of a local power plant, either after capture or directly (Table 6). The percentages of $\mathrm{CO}_{2}$ in the flue gas vary from $5 \%$ (Stephenson et al., 2010) to $15 \%$ (Brentner et al., 2011; Campbell et al., 2011). It is common to point out the lack of knowledge on the long term consequences on algae and on culture facility of the use of flue gas. However Yoo et al. (2010) demonstrated that Botryococcus braunii and Scenedesmus sp. could grow using flue gas as source of carbon. Energetic costs of injection and head losses are always taken into account. The injection of flue gas in the growth medium without prior enrichment or compression requires compressing higher volumes of gas and reduces the efficiency of the gas injection system. Hence there is a clear trade-off in terms of energy consumption between prior purification and gas injections. Some authors (Kadam, 2002; Brentner et al., 2011; Clarens et al., 2011) include to their study the costs of purification and transport. 
Table 6: Different forms of $\mathrm{CO}_{2}$ and steps included in the inventory

\begin{tabular}{|c|c|c|c|c|}
\hline \multirow{2}{*}{ Ref } & \multirow{2}{*}{$\begin{array}{l}\text { Forms of } \mathrm{CO} 2 \text { injected in } \\
\text { the growth medium }\end{array}$} & \multicolumn{3}{|c|}{ Steps included in the inventory } \\
\hline & & Purification & Transport & Injection \\
\hline \multirow{2}{*}{ Kad } & a) Pure $\mathrm{CO}_{2}$ & $\begin{array}{l}\text { a) Yes, from flue gas from power } \\
\text { plants at } 14 \% \text { in } \mathrm{CO}_{2}\end{array}$ & \multirow[t]{2}{*}{ Yes } & \multirow{2}{*}{ Yes } \\
\hline & b) Flue gas at $14 \%$ & b) No & & \\
\hline Lar & NC & No & No & Yes \\
\hline Bal & Pure $\mathrm{CO}_{2}$ & Yes & Yes & Yes \\
\hline Cla10 & Pure $\mathrm{CO}_{2}$ & No & No & No \\
\hline \multirow{3}{*}{ Ste } & a) Flue gas at $12.5 \%$ & \multirow{3}{*}{ No } & \multirow{3}{*}{ No } & \multirow{3}{*}{ Yes } \\
\hline & b) Flue gas at $9 \%$ & & & \\
\hline & c) Flue gas at $5 \%$ & & & \\
\hline \multirow{2}{*}{ Bre } & a) Pure $\mathrm{CO}_{2}$ & $\begin{array}{l}\text { a) No, from flue gas ammoniac plants } \\
\text { at } 100 \% \text { de } \mathrm{CO}_{2}\end{array}$ & \multirow{2}{*}{ No } & \multirow{2}{*}{ Yes } \\
\hline & b) Pure $\mathrm{CO}_{2}$ & $\begin{array}{l}\text { b) Yes, , from flue gas from power } \\
\text { plants at } 15 \% \text { de } \mathrm{CO}_{2}\end{array}$ & & \\
\hline \multirow{2}{*}{ Cam } & a) Pure $\mathrm{CO}_{2}$ & $\begin{array}{l}\text { a) No, from flue gas ammoniac plants } \\
\text { at } 100 \% \text { de } \mathrm{CO}_{2}\end{array}$ & \multirow{2}{*}{ Yes } & \multirow{2}{*}{ Yes } \\
\hline & b) Pure $\mathrm{CO}_{2}$ & $\begin{array}{l}\text { b) Yes, , from flue gas from power } \\
\text { plants at } 15 \% \text { de } \mathrm{CO}_{2}\end{array}$ & & \\
\hline \multirow{3}{*}{ Cla11 } & a) Pure $\mathrm{CO}_{2}$ & a) No & \multirow{3}{*}{ Yes } & \multirow{3}{*}{ Yes } \\
\hline & b) Pure $\mathrm{CO}_{2}$ & b) Yes & & \\
\hline & c) Flue gas at $12.5 \%$ & c) No & & \\
\hline Col & $\begin{array}{l}\text { Pure } \mathrm{CO}_{2}+\mathrm{CO}_{2} \text { recovered } \\
\text { from the purification of } \\
\text { the biogas }+ \text { dissolved } \mathrm{CO}_{2} \\
\text { in the anaerobic digestion } \\
\text { output flow }\end{array}$ & $\begin{array}{c}\text { Yes, just for the } \mathrm{CO}_{2} \text { coming from the } \\
\text { biogas }\end{array}$ & No & Yes \\
\hline Kho & Pure $\mathrm{CO}_{2}$ & No & No & Yes \\
\hline
\end{tabular}

\section{Emissions to the environment}

$\mathrm{CO}_{2}$ emissions occur inevitably in ORW because of the poor efficiency of the injection system and because of the natural outgassing from the growth medium. Only four publications (Kadam, 2002; Stephenson et al., 2010; Campbell et al., 2011; Collet et al., 2011) take into account these losses, with respective emissions of $\mathrm{CO}_{2}$ equal to $0.07 \%, 30 \%, 10 \%$ and $10 \%$. A few studies only consider emissions of other gases. Campbell et al. (2011) consider that $0.11 \%$ of the nitrogen is volatilized without specifying the forms of the emissions. According to Hou et al. (2011), $0.5 \%$ is volatilized as $\mathrm{NH}_{3}$. Finally Batan et al. (2010) mention $\mathrm{NH}_{3}$ volatilization without quantification. 


\subsection{Harvesting and conditioning of the biomass}

It is widely acknowledged that one of the major bottlenecks of bioenergy production from microalgae lies on the concentration step. The selected studies assess a large variety of technologies to achieve concentration, dewatering and sometimes drying of the algal biomass. The final Dry Matter content (DM) before biofuel production depends also on the transformation process. For instance, anaerobic digestion of bulk microalgae requires a low dry matter content, from $5 \%$ (Collet et al., 2011) to $14 \%$ (Clarens et al., 2011). DM content for biodiesel production varies from $14 \%$ (Clarens et al., 2011) in the case of wet extraction to 90\% (Lardon et al., 2009) in the case of dry extraction, and from 50 to $98 \%$ for direct combustion. Table 7 summarizes harvesting and conditioning technologies in regard of the biomass transformation option selected in the different studies. 
Table 7: Conditioning and Dry Matter Content of the algal slurry in regard to its transformation into an energy carrier

\begin{tabular}{|c|c|c|c|c|c|}
\hline \multirow[b]{2}{*}{ Ref } & \multirow{2}{*}{\multicolumn{2}{|c|}{$\begin{array}{l}\text { Harvesting and } \\
\text { conditioning }\end{array}$}} & \multicolumn{3}{|c|}{ Biomass transformation } \\
\hline & & & Electricity & $\begin{array}{c}\text { Oil Extraction - } \\
\text { Transesterification }\end{array}$ & Biogas \\
\hline Kad & $\begin{array}{r}\text { Centrifug } \\
\text { Centrifug } \\
\text { Solar dr }\end{array}$ & $\begin{array}{l}\text { ion } 1: 0.8 \% \\
\text { ion } 2: 12 \% \\
\text { ng : } 50 \%\end{array}$ & $\begin{array}{l}\text { Co-combustion with } \\
\text { coal }\end{array}$ & - & - \\
\hline \multirow[b]{2}{*}{ Lar } & $\begin{array}{r}\text { Floccul } \\
\text { Rotary }\end{array}$ & $\begin{array}{l}\text { ion : } 2 \% \\
\text { ess : } 20 \% \\
\end{array}$ & \multirow[b]{2}{*}{-} & \multirow[b]{2}{*}{ Hexane - Methanol } & \multirow[b]{2}{*}{-} \\
\hline & $\begin{array}{c}\text { Dry } \\
\text { extraction } \\
\text { Belt dryer: } \\
90 \% \\
\end{array}$ & $\begin{array}{c}\text { Wet } \\
\text { extraction } \\
20 \%\end{array}$ & & & \\
\hline Bal & \multicolumn{2}{|c|}{$\begin{array}{c}\text { Centrifugation : } 30 \% \\
\text { Steam drying : } 95 \%\end{array}$} & - & Hexane - Methanol & - \\
\hline Bat & \multicolumn{2}{|c|}{ Centrifugation : NC } & - & Hexane - Methanol & - \\
\hline Cla10 & \multicolumn{2}{|c|}{$\begin{array}{c}\text { Flocculation : NC } \\
\text { Centrifugation : } 10 \%\end{array}$} & - & - & - \\
\hline San & \multicolumn{2}{|c|}{$\begin{array}{c}\text { Filter press : NC } \\
\text { Plate separator : NC } \\
\text { Dryer : } 91 \%\end{array}$} & - & Hexane - Methanol & - \\
\hline Ste & \multicolumn{2}{|c|}{$\begin{array}{c}\text { Flocculation } \\
\text { Centrifugation : } 22 \% \\
\end{array}$} & - & Hexane - Methanol & $\begin{array}{c}\text { Oilcakes : } \\
0.383 \mathrm{~m}^{3} \mathrm{CH}_{4} \cdot \mathrm{kgDM}^{-1} \\
\end{array}$ \\
\hline Bre & \multicolumn{2}{|c|}{$\begin{array}{c}\text { Flocculation } \\
\text { Centrifugation : } 20 \%\end{array}$} & - & $\begin{array}{c}\text { Hexane - Methanol } \\
\text { Supercritical } \mathrm{CO}_{2} \text { - methanol } \\
\text { Sonication + esterification } \\
\text { Supercritical methanol }\end{array}$ & $\begin{array}{c}\text { Oilcakes : } \\
0.800 \mathrm{~m}^{3} \mathrm{CH}_{4} \cdot \mathrm{kgDM}^{-1}\end{array}$ \\
\hline Cam & \multicolumn{2}{|c|}{$\begin{array}{c}\text { Flocculation : NC } \\
\text { Dissolved air flotation : NC }\end{array}$} & - & Hexane - Methanol & $\begin{array}{c}\text { Oilcakes : } \\
0.320 \mathrm{~m}^{3} \mathrm{CH}_{4} \cdot \mathrm{kgDM}^{-1}\end{array}$ \\
\hline Cla11 & \multicolumn{2}{|c|}{$\begin{array}{l}\text { Auto-flocculation : } 1.4 \% \\
\text { Settling : } 14 \%\end{array}$} & $\begin{array}{c}\text { Drying } \\
\text { (90-98\% DM) } \\
\text { Co-combustion with } \\
\text { coal }\end{array}$ & Hexane - Methanol & $\begin{array}{c}\text { Oilcakes : } \\
0.369 \mathrm{~m}^{3} \mathrm{CH}_{4} \cdot \mathrm{kgDM}^{-1} \\
\text { Algae : } \\
0.441 \mathrm{~m}^{3} \mathrm{CH}_{4} \cdot \mathrm{kgDM}^{-1}\end{array}$ \\
\hline Col & \multicolumn{2}{|c|}{$\begin{array}{l}\text { Natural settling: } 1 \% \\
\text { Centrifugation: } 5 \%\end{array}$} & & & $\begin{array}{c}\text { Algae : } \\
0.262 \mathrm{~m}^{3} \mathrm{CH}_{4} \cdot \mathrm{kgDM}^{-1} \\
\end{array}$ \\
\hline Hou & \multicolumn{2}{|c|}{ Flocculation } & - & Hexane - Methanol & - \\
\hline Kho & \multicolumn{2}{|c|}{$\begin{array}{c}\text { Flocculation : } 3 \% \\
\text { Centrifugation : } 15 \%\end{array}$} & - & Hexane - Methanol & - \\
\hline Yan & \multicolumn{2}{|c|}{$: 90 \%$} & - & Hexane - Methanol & - \\
\hline
\end{tabular}

Several studies suggest a first step of flocculation/sedimentation in order to concentrate the biomass

(Erreur ! Source du renvoi introuvable.). It was supposed to be done by $\mathrm{pH}$ adjustment with lime

(Lardon et al., 2009; Brentner et al., 2011), by addition of aluminium sulphate (Clarens et al., 2010;

Stephenson et al., 2010; Brentner et al., 2011), chloride iron (Hou et al., 2011; Khoo et al., 2011) or

chitosan (Brentner et al., 2011). For some species, harvesting can be done by passive sedimentation. 
This first step results in algal slurry with a dry matter content varying from $2 \%$ (Lardon et al., 2009) to 14\% (Clarens et al., 2011). An important issue for the characterization of this step is the determination of the settling velocity and the ratio of biomass staying in the supernatant. Still the concentration of the algal slurry after settling is not high enough to allow efficient down processing. The most classical way to increase further the biomass concentration is centrifugation, even though this method is considered as one of the most energy consuming (Molina Grima et al., 2003). Collet et al. (2011) use data from spiral plate centrifuge, which is reputed to consume less energy; other authors rely on rotary drums (Lardon et al., 2009). Finally, solar drying has been used in one study (Kadam, 2002), which leads to an important decrease of the energetic needs consumptions of this step.

\subsection{Microalgal biomass transformation into energy}

Studied LCAs use three different kinds of energy carriers: electricity obtained by direct combustion of the biomass, biodiesel by sequential or direct triglycerides esterification, and finally biogas by anaerobic digestion.

\section{Electricity production}

Electricity production is the easiest process to develop. Biomass is firstly dried up to 50 or $98 \% \mathrm{DM}$, and then burned in co-combustion with coal. According to Clarens et al. (2011), this transformation path has the lowest impacts on the environment. However it is important to notice that in this study, the needed heat to dry the biomass comes from the recovery of flue gas, and hence is not accounted in the environmental balance neither the energetic balance.

\section{Biodiesel production}

Very scarce data are available to build up an inventory of microalgal oil extraction. Characterisation of the lipid content of microalgae is based on techniques and solvents which cannot be extrapolated to industrial scale techniques, and often the characterisation is done on lyophilised algae, which of 
course is not an option for bioenergy production. Hence inventories for oil extraction and methylester production are most of the times based on inventories of vegetal oil production and transesterification (e.g. rape seed or soybean). Some studies explicit a phase of pre-treatment, based on homogenizer. The rapid compression and decompression of the algal slurry is supposed to disrupt cell walls and hence increase extraction efficiency and digestibility of extraction residues as well (Stephenson et al., 2010; Clarens et al., 2011). Triglycerides are extracted with an organic solvent, the hexane, the lipid and aqueous phases are then separated and the oil/hexane mixture is finally purified by distillation. During the distillation most of the hexane is recovered, hence only a small quantity is lost by volatilization.

In all the concerned studies, triglyceride esterification is performed by reaction with methanol and with alkaline catalysis. This step requires heating, mixing and the addition of a base, most of the time potassium hydroxide. The reaction yield can be significantly reduced by a concurrent saponification reaction, which is enhanced by water. Consequently there is a trade-off between the energy to invest for dewatering and drying the biomass, and the energy for extracting and downprocessing the lipid fraction, with reaction yields drastically affected by the water content. Other approaches have been proposed, such as supercritical $\mathrm{CO}_{2}$ extraction of lipids or in situ esterification. Both approaches could suffer from too high water content. More recently in situ esterification with supercritical methanol has been proposed as a way to overcome this issue. This last option has been selected in the LCAbased optimisation proposed Brentner et al. (2011).

\section{Biogas production}

Finally biomass can be converted into biogas, either directly from the microalgal biomass, or indirectly by the anaerobic digestion of the oilcakes. Different kinds of energies can thus be produced, and the perimeters of the study could be different. Methane potential strongly vary, depending on the species composition and degradability (Sialve et al., 2009). In the considered studies, it ranges from 0.262 (Collet et al., 2011) to $0.800 \mathrm{~m}^{3} \mathrm{CH}_{4} \cdot \mathrm{kgDM}^{-1}$ (Brentner et al., 2011). It should be noticed that this last value is higher than the theoretical maximum value for Scenedesmus 
(Sialve et al., 2009). Energy consumption of anaerobic digesters is most of the time ignored. It is regrettable since long hydraulic retention times required to digest low biodegradable materials (from 10 to 40 days) represent a significant energetic effort for mixing and heating. Heat consumption is estimated at $2.45{\mathrm{MJ} . \mathrm{kg}_{\mathrm{DM}}}^{-1}$ in (Collet et al., 2011) and electricity consumption is estimated at $0 . .47$ MJ. $\mathrm{kg}_{\mathrm{DM}}{ }^{-1}$ in (Brentner et al., 2011) and 0.39 MJ. $\mathrm{kg}_{\mathrm{DM}}{ }^{-1}$ in (Collet et al., 2011).

\section{Environmental impacts assessment}

The inventory phase allows the estimation of all resources, products and emissions required for the production of one unit of the functional unit. This inventory phase will be used to determine potential environmental impacts, including Global Warming Potential, and the energetic balance. In addition to the variability stemming from different process designs or parameter assumptions, the way of handling co-products and the actual method chosen to assess energy balance or environmental impacts will strongly affect the conclusions.

\subsection{The co-products issue}

One of the statements of the LCA methodology is to link every economic and environmental flow to the reference flow of the functional unit. However several processes implied in the production of the functional unit can lead to the production of several products. Two approaches are possible to handle the multi-functionality of the system: allocation or substitution. The allocation approach consists in distributing the environmental burden of the upstream between all the co-products of the multi-output process. This distribution should be based on the most sensitive criterion, e.g. mass, economic value or energetic content of the products. The perimeter expansion (or substitution) option consists in adding the co-product to the functional unit. The ISO norm for LCA stipulates that perimeter expansion should be preferred when possible. When substitution is not possible, energetic allocation should be preferred for processes leading to the production of energy. 
Among the 15 publications, 3 publications analyse systems without co-products (Kadam, 2002; Clarens et al., 2010; Jorquera et al., 2010). Table 8 presents the different co-products and the choice between allocation and substitution. Several processes can lead to co-products:

- The oil extraction process leads to the production of an extraction residue (oilcake) ; only Lardon et al. (2009) chose to use an energy based allocation at this level. Other authors (Stephenson et al., 2010; Brentner et al., 2011; Campbell et al., 2011; Clarens et al., 2011) chose to treat directly the oilcake by anaerobic digestion. Oilcakes can also replace others products: aquaculture or livestock food, carbohydrates' source for bioethanol production.

- Oil esterification produces methylester and glycerol; here economic and energy allocation are often used. In case of substitution, glycerol is mainly used as a source of heat.

- Anaerobic digestion produces biogas, solid and liquid digestates; these digestates can be considered either as waste (and hence cannot support a part of the environmental burden of the process) or as fertilizer or soil conditioner. The liquid digestate can be recirculated to the culturing device and hence substituted to a fraction of the mineral fertilizer required for the algae. The produced biogas is transformed into heat used on site to heat the digesters and / or converted into electricity. Electricity is also consumed on site, and the surplus is injected in the network (Stephenson et al., 2010; Clarens et al., 2011). 
Table 8: Management of the co-products and impact assessment

\begin{tabular}{|c|c|c|c|}
\hline Ref & Management of the co-products & $\begin{array}{l}\text { Energy } \\
\text { balance }\end{array}$ & Impact assessment \\
\hline Kad & No co-product & NER & $\begin{array}{l}\text { Climate change, depletion of natural } \\
\text { resources, acidification, eutrophication } \\
(C M L)\end{array}$ \\
\hline Lar & $\begin{array}{l}\text { Oilcake: energetic allocation } \\
\text { Glycerol : energetic allocation }\end{array}$ & $\begin{array}{l}\text { NER } \\
\text { CED }\end{array}$ & $\begin{array}{c}10 \text { impacts } \\
(\mathrm{CML}) \\
\end{array}$ \\
\hline Bal & $\begin{array}{l}\text { Oilcakes : Substitution with soybean oilcakes } \\
\text { based on their proteins content }\end{array}$ & NER & $\begin{array}{c}\text { Climate change, toxic emissions (air), land } \\
\text { use, acidification (unspecified method) }\end{array}$ \\
\hline Bat & Oilcakes : Substitution with aquaculture food & NER & Climate change (IPCC) \\
\hline Cla10 & No co-product & CED & $\begin{array}{l}\text { Climate change (IPCC), land use, } \\
\text { eutrophication (unspecified method) }\end{array}$ \\
\hline Jor & No co-product & NER & - \\
\hline San & $\begin{array}{l}\text { Oilcakes : Substitution with maize for ethanol } \\
\text { production }\end{array}$ & NER & $\begin{array}{c}\text { Climate change (IPCC), liquid and solid } \\
\text { waste (unspecified method) }\end{array}$ \\
\hline Ste & $\begin{array}{c}\text { Oilcakes: system expansion (anaerobic } \\
\text { digestion to produce biogas) } \\
\text { Digestates are considered as waste } \\
\text { Glycerol: economic allocation on the } \\
\text { pharmaceutical market or substitution to } \\
\text { heat production }\end{array}$ & $\begin{array}{l}\text { NER } \\
\text { CED }\end{array}$ & Climate change (IPCC) \\
\hline Bre & $\begin{array}{c}\text { Oilcake: system expansion (anaerobic } \\
\text { digestion to produce biogas) } \\
\text { Glycerol: economic allocation }\end{array}$ & $\begin{array}{l}\text { NER } \\
\text { CED }\end{array}$ & $\begin{array}{c}\text { Climate change, eutrophication, land use } \\
\text { (TRACI) }\end{array}$ \\
\hline Cam & $\begin{array}{c}\text { Oilcakes: system expansion (anaerobic } \\
\text { digestion to produce biogas) } \\
\text { Digestates considered as waste }\end{array}$ & - & Climate change (Kyoto protocol) \\
\hline Cla11 & $\begin{array}{l}\text { Oilcakes: system expansion (anaerobic } \\
\text { digestion to produce biogas) } \\
\text { Digestates considered as mineral fertilizers }\end{array}$ & $\begin{array}{l}\text { NER } \\
\text { CED }\end{array}$ & Climate change (IPCC) \\
\hline Col & Digestates considered as mineral fertilizers & - & 9 impacts (CML) \\
\hline Hou & $\begin{array}{l}\text { Oilcake: mass allocation } \\
\text { Glycerol : mass allocation }\end{array}$ & NER & 10 impacts $(\mathrm{CML})$ \\
\hline Kho & Not taken into account & NER & Climate change (unspecified) \\
\hline Yan & Not taken into account & - & - \\
\hline
\end{tabular}

\subsection{Energy balance}

As the aim of biofuel production is to provide a substitute to the use of fossil energy, it is important to check that the proposed system manages to create energy and does not use more energy than it produces. Publications use different metrics to evaluate the energy performances of the assessed systems. The Net Energy Ratio (NER), defined as the ratio Produced Energy/Consumed Energy totalizes energy consumption as seen at the facility gate. It means that the consumption of $1 \mathrm{MJ}$ of electricity will be accounted for $1 \mathrm{MJ}$ of invested energy. Other studies measure energy consumption 
in terms of Cumulated Energy (CER); in that case the price of using $1 \mathrm{MJ}$ of electricity will depend on how it has been produced and will measure the total quantity of primary energy used to create the MJ of electricity. Both approaches have their own interest; a NER ratio will focus on the system technology whereas a CER will also include the effect of the technological environment of the production system. None of the approaches consider the fraction of storable energy (which could have been directly used for transportation) mobilized by the process. Table 8 summarizes the environmental and energetic assessment methods.

\subsection{Environmental impacts}

Most of the studies include impacts assessment in their results. Only Yang et al. (2011) limit their publication to the inventory step and Jorquera et al. (2010) only asses the energetic balance. All the other publications assess the potential reduction of greenhouse gases emissions in addition to the energetic balance. However, only three studies estimate other environmental impacts, as defined by the LCA ISO norm, among: abiotic depletion, potential acidification, eutrophication, ozone depletion, human toxicity, marine toxicity, photochemical oxidation, ionizing radiation, land use, freshwater toxicity and terrestrial toxicity. In most of the studies, climate change is assessed with the characterisation factors given by the IPCC (IPCC, 2006) for a temporal horizon of 100 years. Brentner et al. (2011) and Campbell et al. (2011) use different characterisation factors, Khoo et al. (2011) do not present the used methodology to assess climate change. Table 9 illustrates the divergence on characterisation factors between the different methods.

Table 9: Climate change characterization factors of the three main greenhouse gases

\begin{tabular}{|c|c|c|c|}
\hline \multirow{2}{*}{ Gas } & \multicolumn{3}{|c|}{ GWP-100 (g-eq $\mathrm{CO}_{2} \cdot \mathrm{g}^{-1}$ ) } \\
\cline { 2 - 4 } & IPCC & TRACl & Kyoto protocol \\
\hline $\mathrm{CO}_{2}$ & 1 & 1 & 1 \\
\hline $\mathrm{CH}_{4}$ & 25 & 23 & 21 \\
\hline $\mathrm{N}_{2} \mathrm{O}$ & 298 & 296 & 310 \\
\hline
\end{tabular}


Table 10: Greenhouse gas balance of production and use of algal bioenergy

\begin{tabular}{|c|c|c|}
\hline Ref & $\mathrm{CO}_{2}\left(\mathrm{~g} \mathrm{CO}_{2}\right.$ eq $\left./ \mathrm{MJ}\right)$ & Output \\
\hline Kad & 0.061 & Electricity \\
\hline Lar & 59.9 & Biodiesel \\
\hline Bal & 18.5 & Biodiesel \\
\hline Bat & $-75.3^{\mathrm{a}}$ & Biodiesel \\
\hline Cla10 & $-1.31^{\mathrm{b}}$ & Biomass \\
\hline San & 56.8 & Biodiesel \\
\hline Ste & -18.0 & Biodiesel \\
\hline Bre & 13.6 & Biodiesel \\
\hline Cam & $534^{\mathrm{c}}$ & Biodiesel \\
\hline Cla11 & $80.5^{\mathrm{d}}$ & Electricity \\
\hline Col & -0.729 & Methane biofuel \\
\hline Hou & $48.7^{\mathrm{f}}$ & Biodiesel \\
\hline Kho & 61.02 & Biodiesel \\
\hline
\end{tabular}

${ }^{a}$ : combustion is not taken into account, ${ }^{b}$ : combustion is taken into account, ${ }^{c}$ : base configuration, ${ }^{d}$ : best configuration, ${ }^{f}$ : scenario 4D (direct combustion of algal biomass for bioelectricity production),

${ }^{*}$ : extrapolations of figures data

As explained in the previous sections, perimeters, modelling assumptions and impact assessment methods can differ significantly between the different publications. This results in a large variability of the results on the Global Warming Potential (GWP) and the Energy Return On investment (EROI) and hampers the capacity to compare results. However, we gathered results for these two indicators within the selected studies. Table 10 presents the GWP of the different publications and Figure 5 illustrates the relation between Energy Return On Investment and Global Warming Potential. The coproducts management has an important influence on the climate change results. In some studies, climate change impact is negative, which means that the considered system fixes more greenhouse gases than it emits. In Batan et al. (2010), the negative score is due to the substitution of algal oilcakes to soybean oilcakes used to feed livestock. In Sander and Murthy (2010), it corresponds to the substitution of algal oilcakes to maize for the production of bioethanol. Finally in Campbell et al. (2011) it corresponds to the electricity production from biogas produced by anaerobic digestion of the algal oilcakes. 
When only the Net Energy Demand is considered to determine the EROI, favourable values are determined by most of the studies. However when Cumulated Energy is taken into account, the Energy Return on Investment is limited ( 1.8 for the best case, 0.96 for the less favourable). It can also be observed that poor EROI (between 0 and 1) correspond to high GWP.

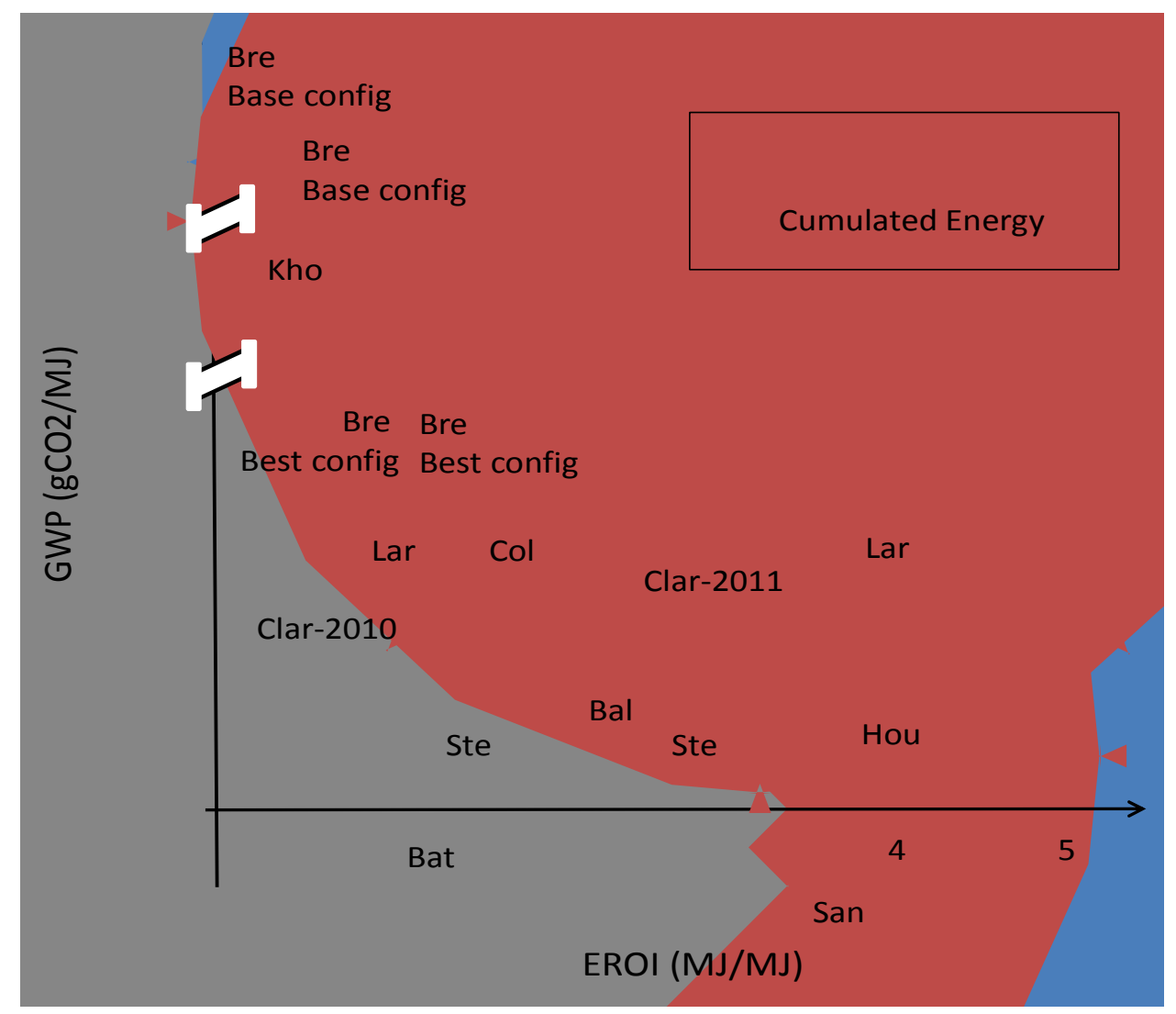

Figure 5 - Global Warming Potential vs. Energy Return On Investment for 1 MJ of biomass and/or biofuel. EROI is expressed in Net Energy (blue) and Cumulated Energy (red).

\section{Discussion and guidelines}

\subsection{Perimeter and Functional Unit}

The non-inclusion of the biofuel combustion from the perimeter of the study can facilitate the comparison between different technologies or energy production pathways but it hampers the assessment of the real carbon balance; indeed some of the carbon atoms of the methylester are 
stemming from methanol, which is usually produced from fossil fuel (Stephenson et al., 2010). Moreover it ignores environmental impacts from the combustion (such as photochemical oxidation, particulate matter formation ...). Finally all engines do not have the same efficiency and hence a fair comparison should be based on the available work produced by the use of the fuel rather than on the chemical property of the fuel only.

In order to harmonize LCA results and provide a better basis for comparisons, the energy content of intermediate products (i.e. raw algae, oil, oil extraction residues, and methylester) should be systematically provided and justified. We also recommend using the Lower Heating Value instead of the Higher Heating Value; indeed in most of the cases, biofuel will be used in engines (e.g. internal combustion engines or turbines) unable to use the energy stored in the water vapour resulting from fuel combustion.

As shown in the former section the choice of using allocation or substitution to handle the multifunctionality of processes has a strong influence on the results. Even though the system expansion is a priori preferable, it can lead to an increase of the overall uncertainty when performances of substituted processes are ill-known (performances of anaerobic digestion of oilcakes) or if the validity of the substitution is questionable (use of oilcake extraction as animal food for instance).

\subsection{Inventory}

Inventory data of microalgal based energy production systems are based on models or extrapolation of lab-scale or pilot-scale data. This is a clear source of uncertainty and variability between studies. Consequently it is important that each new study clearly sources its data and provides detailed inventory data for each process of the production. Hence a mass and energy balance of each process should be provided, with a specific attention to the flow of fossil and biogenic carbon.

Input

It is a common practice when performing LCA of $1^{\text {st }}$ or $2^{\text {nd }}$ generation biofuel to exclude infrastructures. Indeed in these systems, it has been shown that their impact was negligible and the 
inventory of every element of the infrastructure could be a tedious task. On the contrary, algal biomass production requires the construction of culture facilities, raceways or photobioreactors. These two options differ between each other by the type of infrastructure they require, and both differ also from a usual crop by the need of a heavy culture infrastructure. As a consequence LCAs of algae based systems excluding the infrastructure do not allow a fair comparison between different options for algae culture and between algal-based and terrestrial plant-based biofuels.

\section{Culture}

As already pointed, growth rates, biomass composition, $\mathrm{C} / \mathrm{N}$ ratios, fertiliser requirements and energy content of the algae are correlated parameters and hence should not be set according to independent assumptions. We advocate for the definition of chemical properties of each biochemical compartment of the algae (e.g. carbohydrates, lipids, membrane ...) in order to justify the fertilizer budget, the energy content of the raw algae and of the extraction residue. This would hopefully reduce the spread of values for very important parameters such as nutrient requirement, lipid content or growth-rate.

\section{Biomass transformation}

Experimental studies exploring new technologies to extract energy from algal biomass are often based on lyophilised algae or use solvent difficult to use at industrial scale (e.g. chloroform). For instance oil extraction performances and oil esterification yields are of primary importance to realise the LCA of algal biodiesel. Yet, up to now, LCA studies have demonstrated that dry extraction was energetically too expensive but in the same time lack of reliable data to assess the wet extraction path.

Anaerobic digestion is mostly used to produce bioenergy from the obtained residues after lipid extraction. Energetic consumptions should be taken into account, and the potential methane production must be more realistically assessed with existing data, in order to avoid overestimation of the global energetic balance. Operational parameters like the organic loading rate or the hydraulic 
retention time should be specified since they directly influence the energy consumption of the anaerobic process.

\section{Mature versus emerging technologies}

Chosen technologies fort the harvesting, processing and transformation steps are of different levels of maturity between the publications, and even within a study. Some are well known industrial technologies (like cultivation in open ponds for example) but others hazardous extrapolations from lab scale pilot scale studies. Used data in the harvest and extraction steps are particularly variable. For instance, solar drying is used in a study (Kadam, 2002), whereas its feasibility at the industrial scale and the absence of alteration of the lipids content of the algae have not been demonstrated (Lardon et al., 2009). Dry matter content before lipid extraction is also very variable; some authors considering that a percentage of $15-20 \%$ is enough (Lardon et al., 2009; Clarens et al., 2011). This is a wet extraction technology, and the applications at the industrial scale are barely known. To limit the effect of potential unrealistic processes we recommend to study at least two scenarii, one including mature technologies and another one with emerging processes.

\section{Emissions to the environment}

As it has been previously underlined, few publications take into account nitrogen emissions to the environment. We advocate for a better consideration of this problem. Because of the important flow of reactive nitrogen (i.e. ammonia, nitrate or urea), the high concentrations of microorganisms in the culture medium and the occurrence of anoxic conditions during night periods, it is very likely that nitrogen emissions $\left(\mathrm{NH}_{3}\right.$ and $\mathrm{N}_{2} \mathrm{O}$ ) take place at the cultivation system level (Fagerstone et al., 2011). These emissions are harmful to the environment, causing acidification and global warming, $\mathrm{N}_{2} \mathrm{O}$ is indeed a greenhouse gas with a global warming potential much higher than the $\mathrm{CO}_{2}\left(298 \mathrm{~kg}\right.$-eq $\mathrm{CO}_{2}$ . $\mathrm{kg}^{-1}$ at a temporal horizon of 100 years). 
Recent publications put the stress on the question (Frank et al., 2012) or proposed emissions factors derived from lab-scale measurements (Fagerstone et al., 2011) equal to $0.037 \mathrm{gN}_{2} \mathrm{O} \cdot \mathrm{kgN}^{-1}$ in $\mathrm{ORW}$. Indirect emissions of $\mathrm{N}_{2} \mathrm{O}$ due to the transformation of the volatilized ammoniac and nitrous oxides are up to now ignored whereas they can be estimated at $1.6 \mathrm{gN}_{2} \mathrm{O} . \mathrm{kgN}^{-1}$ (IPCC, 2006).

More experimental data are required to provide trustable emission factors. Single emission factors are not satisfying as the control of some parameters of the system, such as the dissolved oxygen content, the $\mathrm{pH}$, the reactive nitrogen concentration and the agitation influence the processes responsible of gas emissions.

\subsection{Impacts assessment}

\section{Climate change and consideration of the biogenic carbon}

An important point in the assessment of the greenhouse gases is the consideration of the fixation of $\mathrm{CO}_{2}$ during photosynthesis in the cultivation step, and the emissions of $\mathrm{CO}_{2}$ during the combustion step (if this last step is included in the perimeter of the study). In the publications of Batan et al. (2010) and Clarens et al. (2010), the fixed $\mathrm{CO}_{2}$ is negatively counted in the global balance of the greenhouse gas (respectively $-75.3 \mathrm{~g} \mathrm{CO}_{2}$ eq. $\mathrm{MJ}^{-1}$ and $-69.4 \mathrm{~g} \mathrm{CO}_{2}$ eq.MJ ${ }^{-1}$ ). But this $\mathrm{CO}_{2}$ is then emitted in the atmosphere during the combustion step. This emission is considered by Batan et al. (2010), but not by Clarens et al. (2010), so in this last case the production of bioenergy from microalgae is a sink of carbon, and the greenhouse balance is widely underestimated. In most of the LCA studies, fixation and then emission of biogenic carbon in the atmosphere are considered as neutral process from a "climate change" point of view. Consequently, most of the authors do not count the fixation of the $\mathrm{CO}_{2}$ during the cultivation step neither the emission during the combustion step. We recommend dedicating a specific attention to this point to guaranty a sound carbon balance. 


\section{Energy balance}

Energy balance should systematically be realised in order to guaranty the consistency of the proposed system with long-term economic constraints. As pointed previously Cumulative Energy and Net Energy ratio can significantly differ by their conclusions. Hence we recommend to always provide both values as the Net Energy Ratio focuses on the performances of the algae production and transformation facility and is independent of country-specific constraints such as the energy mix, whereas the Cumulated Energy Ratio will exhibit the consequences of using inputs with high energy demand such as nitrogen fertilizers or electricity. Our experience showed also that the energy balance is sometimes expressed as the ratio of Produced Energy over Consumed Energy and other times as the ratio of Consumed Energy over Produced Energy. As the first one follows a logic of Return On Investment, the second one follows the logic of impact assessment where resource consumption and effects on the environment are standardised by the functional unit. This duality is confusing for many readers, and we recommend to keep the logic of the Return On Investment as the energy balance is mainly an economic issue.

\section{Other environmental impacts}

The use of a lot of different impacts assessment methodologies can be potentially problematic if one wants to compare LCA studies. For instance, the comparison of the results of the "Eutrophication" impact is not possible between the study of Kadam (2002) and the study of Brentner et al. (2011). In the first case, the used methodology is $\mathrm{CML}$, and the eutrophication impact is expressed in phosphate equivalent, while in in the second publication the used methodology is TRACl, and the impact is expressed in nitrogen equivalent. Moreover some studies do not precise the impact assessment methodology (Clarens et al., 2010, 2011).

A comparison of the LCA results of bioenergy production from microalgae with ones for fossil fuel and other biofuels should be included. The strengths and weaknesses of this new kind of bioenergy 
production compared to fossil fuel or classical bioenergy production from biomass must be identified. Assessed impacts should include climate change and an energetic balance, but impacts which have reduced the interest of first generation biofuel (like land use change occupation or impacts linked with the nitrogen flows or the use of chemical products) and motivated the abandon of fossil fuel (like ozone layer depletion or abiotic resource depletion) should also be presented. A focus should also be done on the quantity and the quality of required water, as evaporation or water spray to cool down the process could lead to a drastic water consumption (Béchet et al., 2010, 2011).

\section{Conclusion}

This chapter presents a critical review of fifteen publications about LCA and bioenergy production from microalgae. The review illustrated the variability of assumptions made about technological and environmental performances of the different processes involved in the production and transformation of algal biomass. The main conclusion of this analysis is that there is a real difficulty to compare the environmental burdens of the proposed set-ups and there is now a need of clear guidelines to ensure that each new LCA study will consolidate the current knowledge. This is of key importance since the objective of LCA works will more and more often consist in guiding the design of new biofuel production systems and prove that they lead to actual progresses in terms of environmental impacts. In this spirit, there is a clear gain for the LCA community to accept a set of rules and guidelines to make any new analysis comparable to the existing ones.

As a consequence, we have proposed some guidelines for the LCA to allow a clearer and sounder comparison between processes and better estimate the potential and challenges of microalgae for biofuel production. 


\section{Bibliography}

Baliga, R., Powers, S.E., 2010. Sustainable Algae Biodiesel Production in Cold Climates. International Journal of Chemical Engineering 2010, 1-13.

Batan, L., Quinn, J., Willson, B., Bradley, T., 2010. Net energy and greenhouse gas emission evaluation of biodiesel derived from microalgae. Environmental science \& technology 44, 7975-80.

Brentner, L.B., Eckelman, M.J., Zimmerman, J.B., 2011. Combinatorial life cycle assessment to inform process design of industrial production of algal biodiesel. Environmental science \& technology 45, 7060-7.

Béchet, Q., Shilton, A., Fringer, O.B., Muñoz, R., Guieysse, B., 2010. Mechanistic modeling of broth temperature in outdoor photobioreactors. Environmental science \& technology 44, 2197-2203.

Béchet, Q., Shilton, A., Park, J.B.K., Craggs, R.J., Guieysse, B., 2011. Universal temperature model for shallow algal ponds provides improved accuracy. Environmental science \& technology 45, 37029.

Börjesson, P., Tufvesson, L.M., 2011. Agricultural crop-based biofuels - resource efficiency and environmental performance including direct land use changes. Journal of Cleaner Production $19,108-120$.

Campbell, P.K., Beer, T., Batten, D., 2011. Life cycle assessment of biodiesel production from microalgae in ponds. Bioresource technology 102, 50-6.

Del Campo, J. a, García-González, M., Guerrero, M.G., 2007. Outdoor cultivation of microalgae for carotenoid production: current state and perspectives. Applied microbiology and biotechnology 74, 1163-74.

Chisti, Y., 2007. Biodiesel from microalgae. Biotechnology advances 25, 294-306.

Clarens, A.F., Nassau, H., Resurreccion, E.P., White, M. a, Colosi, L.M., 2011. Environmental impacts of algae-derived biodiesel and bioelectricity for transportation. Environmental science \& technology 45, 7554-60.

Clarens, A.F., Resurreccion, E.P., White, M. a, Colosi, L.M., 2010. Environmental life cycle comparison of algae to other bioenergy feedstocks. Environmental science \& technology 44, 1813-9.

Collet, P., Hélias, A., Lardon, L., Ras, M., Goy, R.-A., Steyer, J.-P., 2011. Life-cycle assessment of microalgae culture coupled to biogas production. Bioresource technology 102, 207-14.

Doucha, J., Straka, F., Lívanský, K., 2005. Utilization of flue gas for cultivation of microalgae Chlorella sp.) in an outdoor open thin-layer photobioreactor. Journal of Applied Phycology 17, 403-412.

European Union, 2009. Directive 2009/28/EC of the European Parliament and of the Council of 23 April 2009 on the promotion of the use of energy from renewable sources and amending and subsequently repealing Directives 2001/77/EC and 2003/30/EC. 
Fagerstone, K.D., Quinn, J.C., Bradley, T.H., De Long, S.K., Marchese, A.J., 2011. Quantitative measurement of direct nitrous oxide emissions from microalgae cultivation. Environmental science \& technology 45, 9449-56.

Falkowski, P., Raven, J., 1997. Aquatic Photosynthesis.

Frank, E.D., Han, J., Palou-Rivera, I., Elgowainy, A., Wang, M.Q., 2012. Methane and nitrous oxide emissions affect the life-cycle analysis of algal biofuels. Environmental Research Letters 7, 014030.

Goedkoop, M., Heijungs, R., Huijbregts, M., Schryver, A.D., Struijs, J., Zelm, R.V., 2009. ReCiPe 2008a life cycle impact assessment method which comprises harmonised category indicators at the midpoint and the endpoint level.

Hou, J., Zhang, P., Yuan, X., Zheng, Y., 2011. Life cycle assessment of biodiesel from soybean, jatropha and microalgae in China conditions. Renewable and Sustainable Energy Reviews.

Huntley, M.E., Redalje, D.G., 2006. CO2 Mitigation and Renewable Oil from Photosynthetic Microbes: A New Appraisal, Mitigation and Adaptation Strategies for Global Change.

IPCC, 2006. Guidelines for National Greenhouse Gas Inventories, IGED, Japan.

Jorquera, O., Kiperstok, A., Sales, E. a, Embiruçu, M., Ghirardi, M.L., 2010. Comparative energy lifecycle analyses of microalgal biomass production in open ponds and photobioreactors. Bioresource technology 101, 1406-13.

Kadam, K.., 2002. Environmental implications of power generation via coal-microalgae cofiring. Energy 27, 905-922.

Ketchum, B.H., Redfield, A.C., 1949. Some physical and chemical characteristics of algae growth in mass culture. Journal of Cellular and Comparative Physiology 33, 281-299.

Khoo, H.H., Sharratt, P.N., Das, P., Balasubramanian, R.K., Naraharisetti, P.K., Shaik, S., 2011. Life cycle energy and $\mathrm{CO} 2$ analysis of microalgae-to-biodiesel: preliminary results and comparisons. Bioresource technology 102, 5800-7.

Lacour, T., Sciandra, A., Talec, A., Mayzaud, P., Bernard, O., 2012. Neutral Lipid and Carbohydrate Productivities As a Response To Nitrogen Status in Isochrysis Sp. (T-Iso; Haptophyceae): Starvation Versus Limitation1. Journal of Phycology 656, no-no.

Lardon, L., Hélias, A., Sialve, B., Steyer, J.-P., Bernard, O., 2009. Life-Cycle Assessment of Biodiesel Production from Microalgae. Environmental Science \& Technology 43, 6475-6481.

Molina Grima, E., Belarbi, E.-H., Acién Fernández, F.G., Robles Medina, a, Chisti, Y., 2003. Recovery of microalgal biomass and metabolites: process options and economics. Biotechnology advances 20, 491-515.

Sander, K., Murthy, G.S., 2010. Life cycle analysis of algae biodiesel. The International Journal of Life Cycle Assessment 15, 704-714. 
Searchinger, T., Heimlich, R., Houghton, R. a, Dong, F., Elobeid, A., Fabiosa, J., Tokgoz, S., Hayes, D., $\mathrm{Yu}, \mathrm{T} .-\mathrm{H} ., 2$ 2008. Use of U.S. croplands for biofuels increases greenhouse gases through emissions from land-use change. Science (New York, N.Y.) 319, 1238-40.

Shimamatsu, H., 2004. Mass production of Spirulina, an edible microalga. Hydrobiologia 512, 39-44.

Sialve, B., Bernet, N., Bernard, O., 2009. Anaerobic digestion of microalgae as a necessary step to make microalgal biodiesel sustainable. Biotechnology advances 27, 409-16.

Stephenson, A.L., Kazamia, E., Dennis, J.S., Howe, C.J., Scott, S. a., Smith, A.G., 2010. Life-Cycle Assessment of Potential Algal Biodiesel Production in the United Kingdom: A Comparison of Raceways and Air-Lift Tubular Bioreactors. Energy \& Fuels 24, 4062-4077.

Udo de Haes, H., Sleeswijk, A.W., Heijungs, R., 2006. Similarities, Differences and Synergisms Between HERA and LCA-An Analysis at Three Levels. Human and Ecological Risk Assessment: An International Journal 12, 431-449.

Yang, J., Xu, M., Zhang, X., Hu, Q., Sommerfeld, M., Chen, Y., 2011. Life-cycle analysis on biodiesel production from microalgae: water footprint and nutrients balance. Bioresource technology $102,159-65$.

Yoo, C., Jun, S.-Y., Lee, J.-Y., Ahn, C.-Y., Oh, H.-M., 2010. Selection of microalgae for lipid production under high levels carbon dioxide. Bioresource technology 101 Suppl , S71-4. 